УДК $631.811 .1+631.51$

(C) 2013

\author{
Шевченко І. М., аспірант
}

(науковий керівник - кандидат сільськогосподарских наук, професор М. Г. Осінній) Південний філіал Національного університету біоресурсів та природокористування України «Кримський агротехнологічний університет»

\title{
ЗМІНА ВМІСТУ РУХОМОГО ФОСФОРУ В ГРУНТІ ЗА РІЗНИХ СИСТЕМ УДОБРЕННЯ Й ОБРОБІТКУ
}

\section{Рецензент - кандидат сільськогосподарських наук Б. О. Тарасенко}

На підставі багаторічних польових досліджень установлено, щчо в умовах посушливої передгірсько-степової зони Криму в семипільній польовий сівозміні систематичне застосування мінеральних та органо-мінеральних добрив, у тому числі з підвищеною дозою гною, обумовлює стійку тенденцію до збільшення в трунті вмісту рухомого фосфору. На фосфатний режим певною мірою виливає й захід обробітку, оскільки від нього залежить розподіл у грунті рослинних решток і добрив, а крім того впливає сам фактор обертання й перемімування. За багаторічного безполичевого обробітку темпи зростання вмісту фосфору у верхньому шарі нижчі, ніж темпи зниження вмісту изього елемента у нижньому шарі.

Ключові слова: рухомий фосфор, удобрення, обробіток трунту, трунт, сівозміна.

Постановка проблеми. До проблеми землеробства відносять дефіцит фосфору, котрий пов'язаний із малими запасами доступних його форм у природі. Крім того фосфор засвоюється рослинами із добрив. Основним завданням у забезпеченні рослин фосфором є мобілізація грунтових фондів цього елемента і підвищення ефективності використання фосфорних добрив. В останні десятиліття замість традиційного полицевого обробітку грунту все частіше застосовують безполицевий і мілкий. Однак чимало питань їх ефективності залишається не виясненими як у теоретичному, так і у практичному плані: невідома, зокрема, можлива ступінь мінімалізації обробітку тих чи інших грунтів, оптимальне поєднання поверхневих, мілких, звичайних та глибоких, полицевих і безполицевих обробітків.

Кожен із них має як позитивні сторони, так i недоліки. Тому потрібно глибоко вивчати багаторічний їх вплив на основні показники родючості грунту, що здебільшого буде вирішальним у розв'язанні питання, якому заходу або системі обробітку надати перевагу.

Аналіз останніх досліджень і публікацій, у яких започатковано розв'язання проблеми. Проведені в попередні роки дослідження засвідчують, що в результаті дії природних факторів у грунті відбувається диференціація за родючістю.
Навіть у ретельно перемішаному грунті через кілька місяців шар, що залягає вище, стає родючішим, ніж шар, що залягає нижче [5]. Одна із причин такого явища - зміна доступності для рослин фосфору [3].

Більшість результатів досліджень свідчить, що за безполицевих обробітків диференціація грунту за вмістом рухомого фосфору посилюється: підвищується його вміст у верхньому і зменшується у нижньому шарах [3]. $Є$ дані, що за полицевих обробітків не тільки змінюється розподіл фосфатів по профілю грунту, а й збільшується загальна їхня кількість, оскільки при цьому зростає рухомість фосфатів, що $є$ в грунті [1]. Проте в цілому питання впливу різних систем обробітку на загальний вміст рухомого фосфору і розподіл його по профілю грунту, темпи зміни фосфатного режиму грунту за різної тривалості їх застосування, впливу добрив на ці процеси вивчено ще недостатньо.

Мета досліджень: визначити швидкість наростання чи падіння вмісту рухомого фосфору в грунті з часом, залежно від поєднання різних систем удобрення й обробітку і коли кількісні показники перейдуть у якісні і почнуть істотно впливати на врожайність.

Завдання досліджень: аналіз чорнозему південного на вміст рухомого фосфору залежно від поєднання різних систем удобрення й обробітку.

Матеріали і методи досліджень. Фосфатний режим ми вивчали у польовому стаціонарному досліді, закладеному методом розщеплених ділянок. Фактором А були 4 системи удобрення 3 такою кількістю добрив на 1 га сівозмінної площі: 1 - без внесення добрив; 2 - мінеральна на заплановану врожайність $\left(\mathrm{N}_{69,4} \mathrm{P}_{34,8}\right) ; 3$ - органомінеральна (10 т гною, $\left.\mathrm{N}_{30,7} \mathrm{P}_{17,1}\right) ; 4$ - органомінеральна підвищена (20 т гною, $\left.\mathrm{N}_{26,3} \mathrm{P}_{13,0}\right)$. У 2-y і 3-у варіантах кількість азоту і фосфору практично однакова, а в 4-у - на $50 \%$ більша. Калій із мінеральними добривами не вносили оскільки у грунті він міститься у достатній кількості. 


\section{СТОРІНКА МОЛОДОГО ВЧЕНОГО}

Фактором В були 4 системи обробітку грунту: 1 - різноглибинний полицевий (дискування на 8-10 см під пшеницю озиму після кукурудзи на силос; оранка на 28-30 см - під кукурудзу на силос і на 20-22 см - під решту культур); 2 - piзноглибинний безполицевий (глибина як у варіанті 1); 3 - мілкий (на 8-10 cм - під озимі, на 10-12 см під решту культур); 4 - комбінований (під озиму пшеницю після парозаймаючої культури оранка на 20-22 см і після кукурудзи на силос - дискування на 8-10 см, під решту культур - аналогічно варіанту 2).

Схема експериментальної сівозміни у досліді: 1 - пар зайнятий (овес + редька олійна, з 2010 р. (третя ротація) пшениця озима + вика озима); 2 - пшениця озима; 3 - ячмінь озимий; 4 - кукурудза на силос (iз 2006 р. гірчиця на насіння); 5 - пшениця озима; 6 - ячмінь ярий; 7 - льон олійний.

Закладення досліду здійснювалося щорічно 3 1995 р. одним полем, починаючи 3 пару зайнятого. Всього проведено 4 закладки. Повторність досліду - 4-разова, розміщення варіантів 1-го і 2-го порядку рендомізоване. Розмір ділянок із варіантами обробітку грунту $-150 \mathrm{~m}^{2}$. Грунт чорнозем південний. Агротехніка - загальноприйнята для зони. Використовували такі знаряддя обробітку: плуг ПЛН-4-35, плоскорізи КПГ2-150 і КПШ-5, дискову борону БДТ-3.

Зразки грунту для визначення рухомого фосфору відбирали у травні - червні 2011 р. на полі першої закладки досліду (1995р.), яке знаходилося під зайнятим паром із шарів 0-10, 10-20, 20-30 і 30-40 см у 10 точках на ділянці й створювали середній зразок із кожного шару для кожної ділянки. У даному полі дослід триває 16 років; почалася третя ротація сівозміни.

Вміст рухомого фосфору в грунті визначали за Мачигіним. Отримані результати статистично опрацьовували методом дисперсійного аналізу [4]. Залежно від поставленого питання результати аналізів опрацьовували як 3-, 2- і 1-факторний статистичний комплекс. Третім фактором були шари грунту.
Результати досліджень. Результати досліджень у цьому ж досліді на цьому ж полі за 1997-2000 роки (перша ротація) опубліковані раніше [2]. Вони показали, що в шарі грунту 0-40 см порівняно 3 неудобреним варіантом істотне збільшення вмісту рухомого фосфору в грунті у 1-й рік досліджень спостерігалося на органо-мінеральному 3 підвищеною дозою гною, на 2-й і 3-й роки - на всіх удобрених фонах. На мінеральному i органо-мінеральному фонах містилася практично однакова кількість рухомого фосфору, а на органо-мінеральному з підвищеною дозою гною вміст цього елемента був дещо вищим, ніж в інших удобрених варіантах. Фактор часу діяв значно слабше. Істотне зменшення вмісту рухомого фосфору в грунті спостерігалося лише у 1997 р. на неудобреному і мінеральному фонах. Різні системи обробітку однаково впливали на вміст рухомого фосфору в грунті. Не змінився вміст рухомого фосфору в грунті й залежно від тривалості застосування тієї чи іншої системи обробітку. Практично в усіх випадках спостерігалося зменшення рухомого фосфору з глибиною по профілю грунту.

Результати дисперсійного аналізу даних досліджень 2011 року за трифакторною схемою показали суттєву залежність вмісту рухомого фосфору від дії добрив та глибини розміщення шарів грунту, а також взаємодію обробітку і шарів грунту (табл. 1). Для визначення дії часу цікаво порівняти дані 2011 p. і 1997 р., опубліковані раніше [2]. Співставлення цих даних свідчить про відсутність якихось закономірних змін. У 1997 р. вміст рухомого фосфору складав на неудобреному фоні - 2,38 мг/100 г грунту, на мінеральному - 2,70, органо-мінеральному 2,58 і органо-мінеральному з підвищеною дозою гною - 2,97 мг/100 г; через 14 років (2011 р.) вміст фосфору склав: на контролі - 2,12 мг/100 г грунту, на мінеральному - 2,78, органо-мінеральному - 2,81, органо-мінеральному 3 підвищеною дозою гною - 2,79 мг/100 г. Не змінився вміст рухомого фосфору і за різних систем обробітку грунту.

1. Вміст рухомого фосфору в трунті, 2011 р., мг/100 г трунту, головні ефекти

\begin{tabular}{|c|c|c|c|c|c|c|c|}
\hline \multirow{2}{*}{ Фактор } & \multicolumn{4}{|c|}{ Рівень фактора } & \multirow{2}{*}{$\mathrm{F}_{\phi}$} & \multirow{2}{*}{$\mathrm{F}_{05}$} & \multirow{2}{*}{$\mathrm{HIP}_{05}$} \\
\hline & 1 & 2 & 3 & 4 & & & \\
\hline Удобрення, А & 2,12 & 2,78 & 2,81 & 2,79 & 5,43 & 3,07 & 0,65 \\
\hline Обробіток, В & 2,63 & 2,59 & 2,62 & 2,65 & 0,23 & 2,72 & 0,53 \\
\hline Шар грунту, C & 4,26 & 3,44 & 1,86 & 0,95 & 1180,63 & 1,99 & 0,48 \\
\hline
\end{tabular}

Примітка. Для факторів А і В наведено номери згідно зі схемою досліду.

Для фактора С дані за шарами: 1 - 0-10 см; 2-10-20 см; 3 - 20-30 см; 4 - 30-40 см. 
СТОРІНКА МОЛОДОГО ВЧЕНОГО

\section{2. Вплив різних систем добрив на розподіл рухомого фосфору в трунті за різних систем обробітку} та шару трунту, мг/100 г (2011 рік)

\begin{tabular}{|c|c|c|c|c|c|c|c|c|}
\hline \multirow{2}{*}{$\begin{array}{c}\text { Система обробітку } \\
\text { грунту }\end{array}$} & \multicolumn{4}{|c|}{ Шар грунту, см } & \multicolumn{2}{|c|}{$\mathrm{F}$} & \multicolumn{2}{|c|}{ HIP } \\
\hline & $0-10(\mathrm{~K})$ & $10-20$ & $20-30$ & $30-40$ & $\phi$ & 05 & 05 & $\%$ \\
\hline \multicolumn{9}{|c|}{ Без удобрення (К) } \\
\hline 1. Полицева & 3,63 & 2,87 & 1,63 & 0,74 & 17,88 & 3,88 & 0,970 & 43,78 \\
\hline 2. Безполицева & 3,68 & 2,37 & 1,28 & 0,81 & 15,90 & 3,88 & 1,023 & 50,34 \\
\hline 3. Мілка & 3,66 & 2,62 & 1,58 & 0,75 & 26,04 & 3,88 & 0,794 & 36,90 \\
\hline 4. Комбінована & 3,68 & 2,60 & 1,22 & 0,85 & 112,0 & 3,88 & 0,393 & 18,82 \\
\hline $\mathrm{F}_{\phi}$ & 0,01 & 1,36 & 1,26 & 1,14 & & & & \\
\hline $\mathrm{F}_{05}$ & 3,07 & 3,07 & 3,07 & 3,07 & & & & \\
\hline $\mathrm{HIP}_{05}$ & 0,75 & 0,51 & 0,54 & 0,15 & & & & \\
\hline $\mathrm{HIP}_{\%}$ & 20,6 & 19,7 & 38,22 & 19,76 & & & & \\
\hline \multicolumn{9}{|c|}{ Мінеральна } \\
\hline 1. Полицева & 3,91 & 3,22 & 2,63 & 1,03 & 9,22 & 3,88 & 1,294 & 48,01 \\
\hline 2. Безполицева & 4,81 & 3,83 & 2,18 & 0,91 & 43,04 & 3,88 & 0,844 & 28,75 \\
\hline 3. Мілка & 5,23 & 3,41 & 1,56 & 0,85 & 44,74 & 3,88 & 0,940 & 34,05 \\
\hline 4. Комбінована & 4,65 & 3,20 & 1,95 & 1,11 & 19,95 & 3,88 & 1,106 & 40,62 \\
\hline $\mathrm{F}_{\phi}$ & 4,62 & 0,70 & 5,11 & 3,40 & & & & \\
\hline $\mathrm{F}_{05}$ & 3,07 & 3,07 & 3,07 & 3,07 & & & & \\
\hline $\mathrm{HIP}_{05}$ & 0,75 & 1,03 & 0,58 & 0,18 & & & & \\
\hline $\mathrm{HIP}_{\%}$ & 16,18 & 30,2 & 28,21 & 18,81 & & & & \\
\hline \multicolumn{9}{|c|}{ Органо-мінеральна } \\
\hline 1. Полицева & 4,03 & 3,88 & 2,30 & 0,97 & 47,93 & 3,88 & 0,669 & 23,96 \\
\hline 2. Безполицева & 4,29 & 3,85 & 1,59 & 0,94 & 43,87 & 3,88 & 0,796 & 29,86 \\
\hline 3. Мілка & 4,51 & 3,98 & 1,93 & 0,98 & 22,40 & 3,88 & 1,131 & 39,65 \\
\hline 4. Комбінована & 4,79 & 4,12 & 1,36 & 1,10 & 99,09 & 3,88 & 0,606 & 21,33 \\
\hline$F_{\phi}$ & 4,97 & 0,75 & 1,79 & 1,71 & & & & \\
\hline $\mathrm{F}_{05}$ & 3,07 & 3,07 & 3,07 & 3,07 & & & & \\
\hline $\mathrm{HIP}_{05}$ & 0,43 & 0,39 & 0,66 & 0,16 & & & & \\
\hline $\mathrm{HIP}_{\%}$ & 9,77 & 9,96 & 35,12 & 16,21 & & & & \\
\hline \multicolumn{9}{|c|}{ Органо-мінеральна підвищена } \\
\hline 1. Полицева & 4,03 & 3,82 & 2,51 & 0,93 & 53,26 & 3,88 & 0,626 & 22,18 \\
\hline 2. Безполицева & 4,27 & 3,62 & 1,82 & 1,25 & 147,4 & 3,88 & 0,378 & 13,82 \\
\hline 3. Мілка & 4,54 & 3,71 & 1,69 & 0,98 & 62,87 & 3,88 & 0,674 & 24,71 \\
\hline 4. Комбінована & 4,37 & 3,96 & 2,11 & 1,07 & 159,3 & 3,88 & 0,394 & 13,70 \\
\hline $\mathrm{F}_{\phi}$ & 5,21 & 3,09 & 15,54 & 4,13 & & & & \\
\hline $\mathrm{F}_{05}$ & 3,07 & 3,07 & 3,07 & 3,07 & & & & \\
\hline $\mathrm{HIP}_{05}$ & 0,27 & 0,24 & 0,27 & 0,198 & & & & \\
\hline $\mathrm{HIP}_{\%}$ & 6,28 & 6,47 & 13,41 & 18,78 & & & & \\
\hline
\end{tabular}

У 1997 р. за полицевого обробітку у середньому по всіх фонах добрив його вміст складав 2,67 , за безполицевого - 2,62, мілкого $-2,69$ i комбінованого - 2,66 мг/100 г, а в 2011 р. по обробітках грунту вміст рухомого фосфору склав за полицевим обробітком - 2,63 мг/100 г грунту, за безполицевим - 2,59, за мілкого - 2,62 і комбінованого - 2,66 мг/100 г.

Значно відчутнішими були поєднання систем удобрення і систем обробітку з огляду на розподіл рухомого фосфору по шарах грунту (табл. 2).
Наведені дані свідчать, що на фоні без добрив у шарі 0-10 см вміст рухомої $\mathrm{P}_{2} \mathrm{O}_{5}$ не відрізнявся при системах обробітку грунту, що вивчалися. В шарі 10-20 см за полицевого обробітку спостерігався найвищий вміст рухомої $\mathrm{P}_{2} \mathrm{O}_{5}$ (2,87 мг/100 г грунту), що підтверджує дані літературних джерел про найменш виражену диференціацію орного шару за родючістю за різноглибинного полицевого обробітку. Порівняно 3 безполицевим та комбінованим обробітком така ж залежність спостерігається і в шарі 20-30 cм. 


\section{СТОРІНКА МОЛОДОГО ВЧЕНОГО}

За рахунок внесення мінеральних добрив суттєве зростання вмісту рухомої $\mathrm{P}_{2} \mathrm{O}_{5}$ спостерігається при безполицевому, мілкому та комбінованому обробітках у шарі 0-10 см і безполицевому та мілкому обробітках у шарі 10-20 см (приріст вмісту $\mathrm{P}_{2} \mathrm{O}_{5}$ від мінеральних добрив становив, відповідно, 1,$13 ; 1,57$ та $0,97 \mathrm{мг} / 100$ г грунту в шарі $0-10$ см та 1,46 і 0,79 мг/100г грунту в шарі 10-20 см при $\mathrm{HIP}_{05}=0,65$ мг $/ 100$ г грунту).

Суттєве зростання вмісту рухомого фосфору від застосування мінеральних добрив у шарі 20$30 \mathrm{~cm} \mathrm{спостерігається} \mathrm{лише} \mathrm{за} \mathrm{полицевого} \mathrm{обро-}$ бітку $(1,0 \mathrm{Mг} / 100$ г грунту) та безполицевого $(0,90$ мг/100 г) за рахунок просипання добрив за стійками плоскорізу. Це також свідчить про більш рівномірний розподіл мінеральних добрив в орному шарі грунту за полицевого обробітку. В цілому за рахунок внесення мінеральних добрив вміст рухомої $\mathrm{P}_{2} \mathrm{O}_{5}$ у $0-40 \mathrm{~cm}$ шарі зростав за всіх систем обробітку - 32,12 мг/100 г на неудобреному фоні до 2,78-2,81 мг/100 г грунту - на фоні мінеральних добрив.

На фоні органо-мінеральних добрив із внесенням 10 т/га сівозмінної площі гною спостерігалось аналогічна залежність; лише в шарі 20$30 \mathrm{~cm}$ суттєве зростання рухомої $\mathrm{P}_{2} \mathrm{O}_{5}$ спостерігалося тільки за полицевого обробітку.

В усіх поєднаннях системи обробітку і систем удобрення найменш суттєва диференціація родючості грунту по орному шару відмічалася в разі полицевого обробітку.

Багаторічна дія та післядія систем обробітку грунту у поєднанні $з$ різними системами удобрення за комплексної їх у польовій сівозміні оці-

\section{БІБЛІОГРАФІЯ}

1. Відтворення родючості грунтів у грунтозахисному землеробстві / За ред. М. К. Шикули. К. : Оранта, 1998. - 680 c.

2. Гордієнко В. П., Сичевський С. М. Фосфатний режим грунту за різних систем удобрення й обробітку // Вісник аграрної науки, 2001. - №5. C. 11-14.

3. Гордієнко В. П., Малієнко А. М., Грабак Н. Х. Прогресивні системи обробітку грунту. - Сімфе- нки свідчить, що тривале застосування полицевого, безполицевого, мілкого та комбінованого обробітків повинні здійснюватися за результатами не лише показників родючості грунту, але й врожайності сільськогосподарських культур та еколого-економічної оцінки.

Висновки. Таким чином, у наших дослідженнях підтверджена найменша диференціація за родючістю орного шару (0-30 см) за поєднання внесення мінеральних та органо-мінеральних добрив із багаторічним застосуванням різноглибинного полицевого й комбінованого обробітків.

Разом із тим, слід зазначити, що в орному (0-30 см) шарі грунту за такого поєднання за всіх систем обробітку грунту досягається середній та підвищений вміст рухомої $\mathrm{P}_{2} \mathrm{O}_{5}$, що забезпечує високу ефективність застосування азотних добрив та одержання рівноцінного врожаю пшениці озимої.

Інакше кажучи, застосування мінеральних $\mathrm{i}$ органо-мінеральних добрив на чорноземах південних 3 огляду на вміст рухомої $\mathrm{P}_{2} \mathrm{O}_{5}$ обов'язково повинно поєднуватися з полицевим обробітком у сівозміні на грунтах із дуже низьким $(<1)$ та низьким $(1-1,5$ мг/100 г грунту рухомої $\mathrm{P}_{2} \mathrm{O}_{5}$ ) вмістом рухомих форм фосфору (за Мачигіним).

Питання щодо доцільності поєднання внесення зазначених добрив із мілким та полицевим обробітком повинне вирішуватися 3 урахуванням інших чинників родючості грунту та врожайності вирощуваних культур із кінцевою економічною оцінкою такого поєднання.

рополь : Кримська Академія гуманітарних наук, 1998. - $279 \mathrm{c}$.

4. Литтлл Т. М., Хиллз Ф. Дж. Сельскохозяйственное опытное дело. Планирование и анализ / Пер. с англ. - М. : Колос, 1981. - 320 с.

5. Ревут И. Б. Вопросы теории обработки почвы / Теоретические вопросы обработки почв. Л. : Гидрометеоиздат, 1968. - С. 7-18. 